\title{
Role of Inhibitory and Stimulative Effects of Prostaglandins on Vasopressin-stimulated Osmotic Water Flow in the Toad Bladder
}

\author{
Fumiaki Marumo with the technical assistance of Yoshihiro Nara \\ Department of Medicine, Kitasato University School \\ of Medicine, Sagamihara, 228 Japan
}

\begin{abstract}
Vasopressin-prostaglandin (PG) interaction, especially the role of the inhibitory effects of $\mathrm{PGE}_{2}$ on vasopressin action, was studied using toad urinary bladders. The $\mathrm{PGH}_{2}$, at $1 \times 10^{-7} \mathrm{M}$, inhibited vasopressinstimulated water flow (MARUMO, 1982); $\mathrm{PGE}_{2}$ inhibited the water flow at $10^{-8} \mathrm{M}$, but $\mathrm{PGD}_{2}, \mathrm{PGF}_{2 \alpha}$, and $\mathrm{PGI}_{2}$ did not do so even at $10^{-7} \mathrm{M}$. Thus, $\mathrm{PGE}_{2}$ has a physiological effect in contrast to other PGs converted from $\mathrm{PGH}_{2}$. Indomethacin enhanced both the vasopressin- and cyclic AMPstimulated water flow across the toad bladder. However, the half maximum activation dose for vasopressin was $2 \times 10^{-10} \mathrm{M}$, but for cyclic AMP, as much as $3 \times 10^{-8} \mathrm{M}$. The $\mathrm{PGE}_{2}$ inhibited both vasopressin- and cyclic AMP-stimulated water flow. However, $\mathrm{PGE}_{2}$ inhibited vasopressin action in a dose-dependent manner which was not noted as a $\mathrm{PGE}_{2}$ effect on cyclic AMP action. The W-7, which is a specific inhibitor of calmodulin, suppressed cyclic AMP-stimulated water flow in a dese-dependent manner. Thus, $\mathrm{PGE}_{2}$ may suppress vasopressin-stimulated water flow at a site of cyclic AMP generation under physiological conditions. Thromboxane $\mathrm{B}_{2}\left(\mathrm{TXB}_{2}\right)$ enhanced vasopressin-stimulated water flow but not cyclic AMP-stimulated one. Thus $\mathrm{PGE}_{2}$ and $\mathrm{TXB}_{2}$ may be concluded as negative or positive modulators of vasopressin action in the toad bladder on the step(s) as the site of cyclic AMP generation under physiological conditions.
\end{abstract}

Key words: vasopressin, prostaglandins, toad bladder, osmotic water flow, $\mathrm{PGE}_{2}$.

ORLOFF et al. (1965) were the first to report that prostaglandin $\mathrm{E}_{1}\left(\mathrm{PGE}_{1}\right)$ inhibits vasopressin- and theophylline-induced water flow across the toad bladder but not that induced by cyclic AMP. OMACHI et al. (1974) found $\mathrm{PGE}_{1}$ diminished the accumulation of cyclic AMP in response to vasopressin in the toad bladder, and thus concluded that $\mathrm{PGE}_{1}$ suppresses vasopressin-stimulated water flow by inhibiting adenylate cyclase activity. This is supported by other reports in which

Received for publication May 26, 1986 
mammalian tissues were used. MARUMO and EDELMAN (1971) previously reported that $\mathrm{PGE}_{1}$ inhibits adenylate cyclase activity in the hamster kidney, and BECK et al. (1971) found the same in the rat kidney. However, SHLONDORFF et al. (1981) observed that $\mathrm{PGE}_{2}$ inhibited cyclic AMP-stimulated water flow when the bladders were pretreated with prostaglandin synthesis inhibitors, but had no effect on water flow (Orloff et al., 1965; Flores and Sharp, 1972; Albert and HANDler, 1974). SCHLONDORFF et al. (1981) suggest that $\mathrm{PGE}_{2}$ interferes with the stimulation of water flow at both "post cyclic AMP" and "pre cyclic AMP" sites, but they have not clarified at which of these two sites $\mathrm{PGE}_{2}$ exerts its effects against vasopressin under physiological conditions.

Thromboxane $\mathrm{B}_{2}\left(\mathrm{TXB}_{2}\right)$ has been shown in several reports to enhance vasopressin-stimulated water flow (BuRCH et al., 1979; BISORDI et al., 1980; BuRCH and HalushKa, 1982). But the authors of those reports do not provide a clear indication as to whether the effects of $\mathrm{TXB}_{2}$ are exerted at the site of or distal to cyclic AMP generation.

In the present study, we attempted 1) to examine the effects of prostaglandins on vasopressin-stimulated water flow across the toad bladder, 2) to determine whether the inhibitory effect of $\mathrm{PGE}_{2}$ is exerted at the site of cyclic AMP generation or on a step after cyclic AMP generation under the physiological conditions, and 3) to determine whether the stimulatory effect of $\mathrm{TXB}_{2}$ is exerted at the site or distal to cyclic AMP generation.

\section{MATERIALS AND METHODS}

Urinary bladders of the toad, Bufo bufo japonicus, reared on the ground surface for 1-4 weeks were used. After double pithing, the urinary bladders were immediately removed, placed in Ringer's solution, excised and halved. Each hemibladder was mounted in a glass chamber. To present mechanical distortion of the bladder membrane, both chamber orifices were covered with a nylon mesh as previously described (MARUmo and KIKAWADA, 1974). To measure the osmotic water flow volumetrically, Ringer's solution diluted by a fifth was introduced into the mucosal chamber. The area of either chamber orifice was $2.66 \mathrm{~cm}^{2}$. The composition of Ringer's solution was as follows (in $\mathrm{mm}$ ): $\mathrm{NaCl}, 111 ; \mathrm{KCl}, 3.5$; $\mathrm{CaCl}_{2}, 0.9 ; \mathrm{MgCl}_{2}, 1.5 ; \mathrm{NaH}_{2} \mathrm{PO}_{4}, 1.9 ; \mathrm{Na}_{2} \mathrm{HPO}_{4}, 8.1$. The osmolality was $232 \mathrm{mOsM} / l$ and the $\mathrm{pH}$ 7.4.

Prostaglandin $\mathrm{E}_{1}\left(\mathrm{PGE}_{1}\right), \mathrm{PGE}_{2}, \mathrm{PGD}_{2}, \mathrm{PGF}_{2 \alpha}, \mathrm{PGI}_{2}$, and $\mathrm{TXB}_{2}$ were purchased from Sigma (St. Louis). Adenosine 3',5'-monophosphate (cyclic AMP) was obtained from Yamasa Shoyu (Choshi, Japan), N-(6-aminohexyl)-5-chloro-1naphthalenesulfonamide (W-7) from Shikagaku Kogyo (Tokyo), and vasopressin (Pitressin ${ }^{\circledR}$ ) from Park-Davis (Detroit). Indomethacin and prostaglandins were dissolved in ethanol, cyclic AMP in Ringer's solution and adjusted to a $\mathrm{pH}$ of 7.4 with $0.1 \mathrm{~N} \mathrm{NaOH}$. The other drugs were dissolved in distilled water. All drugs were introduced into the chamber from the serosal side. Prostaglandins dissolved in 
$0.1 \mathrm{ml}$ ethanol were applied into $15 \mathrm{ml}$ Ringer's solution of the experimental chamber, and $0.1 \mathrm{ml}$ ethanol to the control. When indomethacin or W-7 was used, pre-incubation with the drugs was performed for $30 \mathrm{~min}$ or $1 \mathrm{~h}$, respectively, before the addition of vasopressin or cyclic AMP.

\section{RESULTS}

1. Effects of $P G E_{2}, P G D_{2}, P G F_{2 \alpha}, P G I_{2}$ on vasopressin-stimulated osmotic water flow

As previously reported (MARUMO, 1982), $\mathrm{PGH}_{2}$ inhibits the vasopressinstimulated osmotic water flow of the toad bladder. Effects of products of $\mathrm{PGH}_{2}$, such as $\mathrm{PGE}_{2}, \mathrm{PGD}_{2}, \mathrm{PGF}_{2 \alpha}$, and $\mathrm{PGI}_{2}$ on the water flow were examined. Table 1 shows the effects of prostaglandins on the $10 \mathrm{mU} / \mathrm{ml}$ vasopressin-stimulated water flow. The $\mathrm{PGE}_{2}$ showed an inhibitory effect at $10^{-8} \mathrm{M}$, but $\mathrm{PGF}_{2 \alpha}, \mathrm{PGI}_{2}$, and $\mathrm{PGD}_{2}$ failed to do so even at $10^{-7} \mathrm{M}$, although $\mathrm{PGF}_{2 \alpha}$ was effective at $10^{-6}$ and $10^{-5} \mathrm{M}$ (Table 1). None of these prostaglandins by itself was found to have any effect on the osmotic water flow unless vasopressin was present.

2. Effects of $P G E_{2}$ on vasopressin- and cyclic AMP-stimulated water flow

Figure 1 shows the effects of indomethacin on vasopressin- and cyclic AMPstimulated water flow in the toad bladder. Indomethacin was added to the serosal

Table 1. Effects of prostaglandins on vasopressin-stimulated water flow in the toad bladder.

\begin{tabular}{clllll}
\hline $\begin{array}{c}\text { Concentra- } \\
\text { tion }(\mathrm{M})\end{array}$ & \multicolumn{1}{c}{$\mathrm{PGE}_{1}$} & \multicolumn{1}{c}{$\mathrm{PGE}_{2}$} & \multicolumn{1}{c}{$\mathrm{PGF}_{2 \alpha}$} & \multicolumn{1}{c}{$\mathrm{PGI}_{2}$} & \multicolumn{1}{c}{$\mathrm{PGD}_{2}$} \\
\hline $10^{-5}$ Cont. & & & $3.35 \pm 1.16$ & $3.31 \pm 0.71$ & $2.92 \pm 0.52$ \\
Exp. & & & $1.37 \pm 0.44$ & $3.36 \pm 0.60$ & $2.87 \pm 1.11$ \\
& & & $n=6, p<0.01$ & $n=6, p:$ n.s. & $n=6, p:$ n.s. \\
$10^{-6}$ Cont. & & & $2.51 \pm 0.62$ & $3.64 \pm 1.27$ & $3.54 \pm 0.99$ \\
Exp. & & & $1.66 \pm 0.48$ & $3.64 \pm 0.77$ & $3.17 \pm 1.51$ \\
& & $3.55 \pm 0.70$ & $2.62 \pm 0.23$ & $3.42 \pm 0.75$ & $3.10 \pm 1.04$ \\
$10^{-7}$ Cont. & & $1.98 \pm 0.53$ & $2.55 \pm 0.83$ & $3.45 \pm 0.94$ & $3.49 \pm 1.11$ \\
Exp. & & $n=6, p<0.0025$ & $n=6, p: \mathrm{n} . \mathrm{s}$. & $n=6, p: \mathrm{n} . \mathrm{s}$. & $n=6, p: \mathrm{n} . \mathrm{s}$. \\
$10^{-8}$ Cont. & $3.30 \pm 0.61$ & $3.59 \pm 0.60$ & & & \\
Exp & $2.24 \pm 0.60$ & $2.43 \pm 0.95$ & & & \\
& $n=6, p<0.05$ & $n=6, p<0.05$ & & & \\
$10^{-9}$ Cont. & $3.24 \pm 1.41$ & $2.86 \pm 0.88$ & & & \\
Exp. & $2.84 \pm 1.13$ & $2.71 \pm 0.52$ & & & \\
& $n=9, p:$ n.s. & $n=9, p$ : n.s. & & & \\
\hline
\end{tabular}

$\mu \mathrm{l} / \mathrm{min}$, mean \pm S.D. Cont. indicates the control group, and Exp. that of the experimental. The concentration of vasopressin added was $10 \mathrm{mU} / \mathrm{ml}$. 


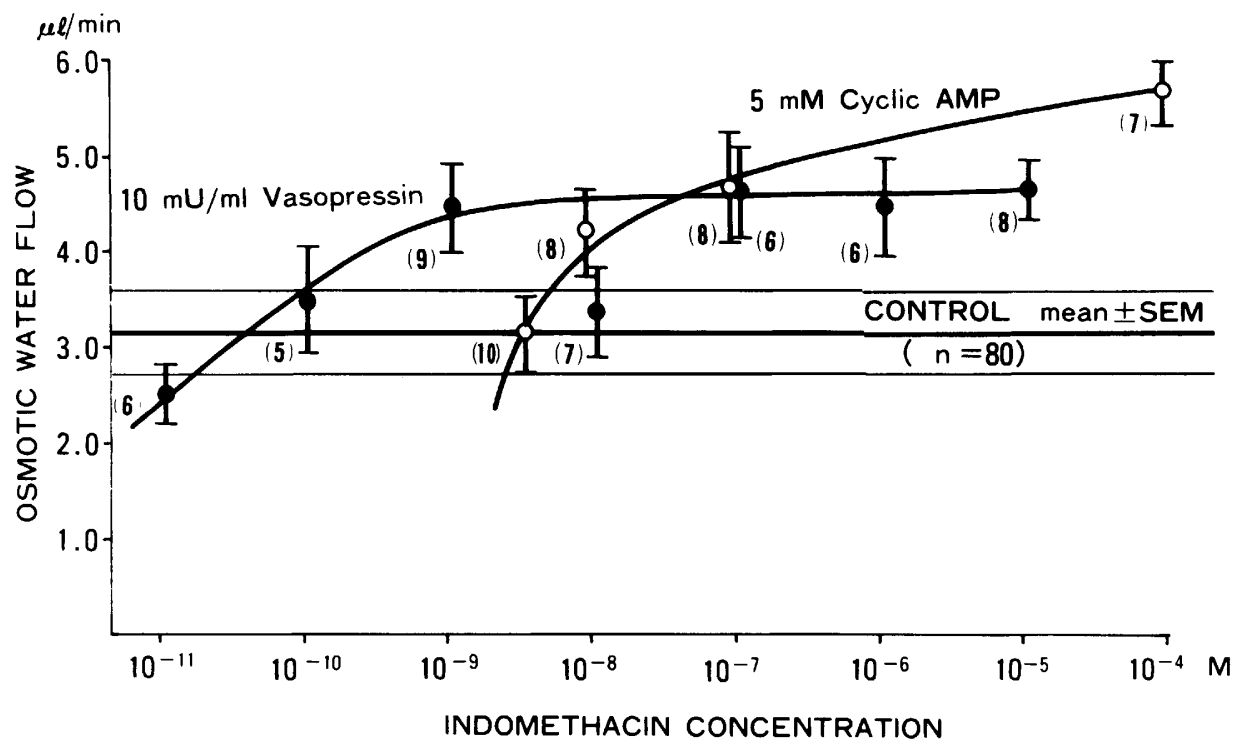

Fig. 1. Effects of indomethacin on vasopressin- and cyclic AMP-stimulated water flow in the toad bladder. Indomethacin was added to the serosal chamber $30 \mathrm{~min}$ prior to the addition of the above agents. The vertical line indicates the mean \pm S.E.M., and the numbers of experiment are given in parentheses.

chamber $30 \mathrm{~min}$ before the addition of either vasopressin or cyclic AMP. Indomethacin significantly increased vasopressin-stimulated water flow at the doses higher than $10^{-9} \mathrm{M}$, and cyclic AMP-stimulated flow at the doses higher than $10^{-8} \mathrm{M}$. The figure shows a dissociation of indomethacin effects on vasopressin and cyclic AMP. The half maximum activation dose for vasopressin was $2 \times 10^{-10} \mathrm{M}$, while that for cyclic AMP was $3 \times 10^{-8} \mathrm{M}$. Indomethacin, at $10^{-4} \mathrm{M}$, continued to show its effect on the cyclic AMP-stimulated water flow, but this effect may be due to the inhibitory effect on phosphodiesterase activity instead of prostaglandin synthesis inhibition. Flores and SHARP (1972) reported indomethacin to show an inhibitory effect on phosphodiesterase at high concentration, and the inhibitory effect of $2.8 \times 10^{-6} \mathrm{M}$ indomethacin on the enzyme activity to be equivalent to $5 \times$ $10^{-5} \mathrm{M}$ theophylline.

Figure 2 shows the effects of $\mathrm{PGE}_{2}$ on vasopressin- and cyclic AMP-stimulated water flow. All drugs were added to the serosal chamber after 30 min pre-incubation with $1 \times 10^{-6} \mathrm{M}$ indomethacin. Figure 2 shows percent inhibition of vasopressin- or cyclic AMP-stimulated water flow with the addition of $\mathrm{PGE}_{2} . \mathrm{PGE}_{2}$ inhibits the water flow in a dose-dependent manner as evident from the figure. On the other hand, $\mathrm{PGE}_{2}$ inhibits cyclic AMP-stimulated water flow at both $10^{-8}$ and $10^{-7} \mathrm{M}$, but not at $10^{-9}$ and $10^{-6} \mathrm{M}$. However, the calmodulin inhibitors, which inhibit vasopressin action at steps following cyclic AMP generation (LEVINE et al., 1981) 


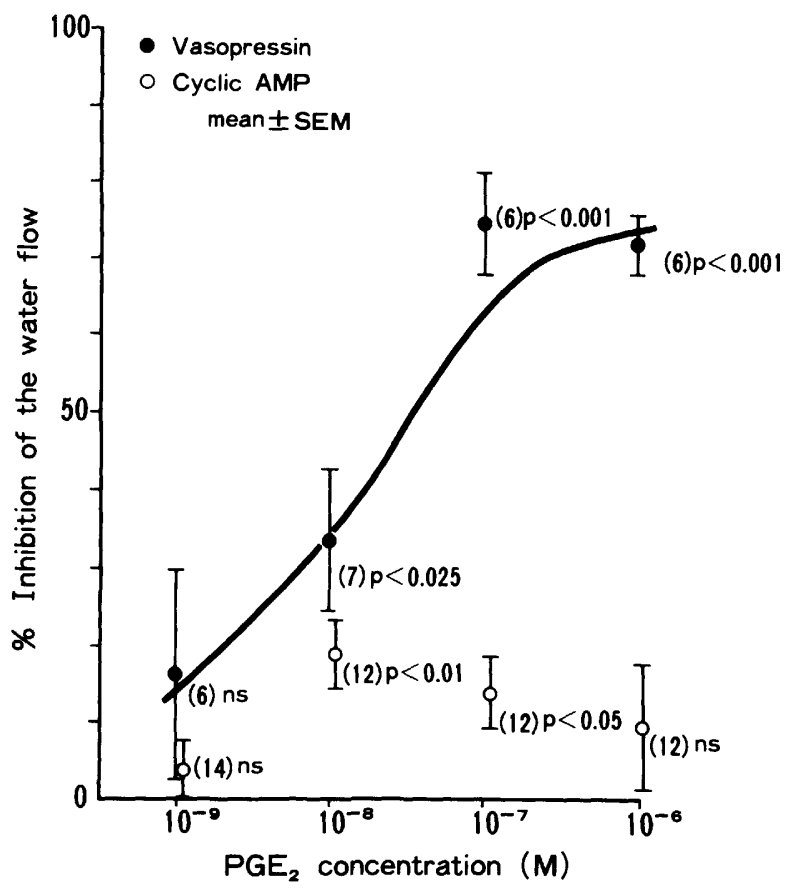

Fig. 2. Effects of $\mathrm{PGE}_{2}$ on vasopressin- and cyclic AMP-stimulated water flow. Bladders were pre-incubated with $1 \times 10^{-6} \mathrm{M}$ indomethacin $30 \mathrm{~min}$ prior to the addition of the agents. The concentrations of vasopressin and cyclic AMP were $10 \mathrm{mU} / \mathrm{ml}$ and $5 \mathrm{~mm}$, respectively.

such as W-7 (HidaKa et al., 1978) (Fig. 3) or trifluoperazine (data not shown), suppressed cyclic AMP-stimulated water flow in a dose-dependent manner. The $\mathrm{PGE}_{2}$ showed no effect on cyclic AMP-stimulated water flow at $10^{-10} \mathrm{M}$.

3. Effects of thromboxane $B_{2}$ on vasopressin-and cyclic AMP-stimulated water flow

Thirty min following pre-incubation of bladders with $1 \times 10^{-6} \mathrm{M}$ indomethacin, $\mathrm{TXB}_{2}$ with either vasopressin or cyclic AMP was introduced into the serosal chambers. In Fig. $4, \mathrm{TXB}_{2}$ significantly stimulates the $10 \mathrm{mU} / \mathrm{ml}$ vasopressin-stimulated water flow at a concentration of $1 \times 10^{-7} \mathrm{M}$ but not at $10^{-8} \mathrm{M}$. However, $\mathrm{TXB}_{2}$ shows no effect on the $5 \mathrm{mM}$ cyclic AMP-stimulated water flow either at $10^{-7}$ or $10^{-6} \mathrm{M}$ in Fig. 5. $\mathrm{TXB}_{2}$ alone, at $10^{-6} \mathrm{M}$, had no effect on the water flow.

\section{DISCUSSION}

A previous report (MARUMO, 1982) showed $\mathrm{PGH}_{2}$ to inhibit vasopressinstimulated water flow in the toad bladder, at a concentration of $1 \times 10^{-7} \mathrm{M}$. Of the 4 


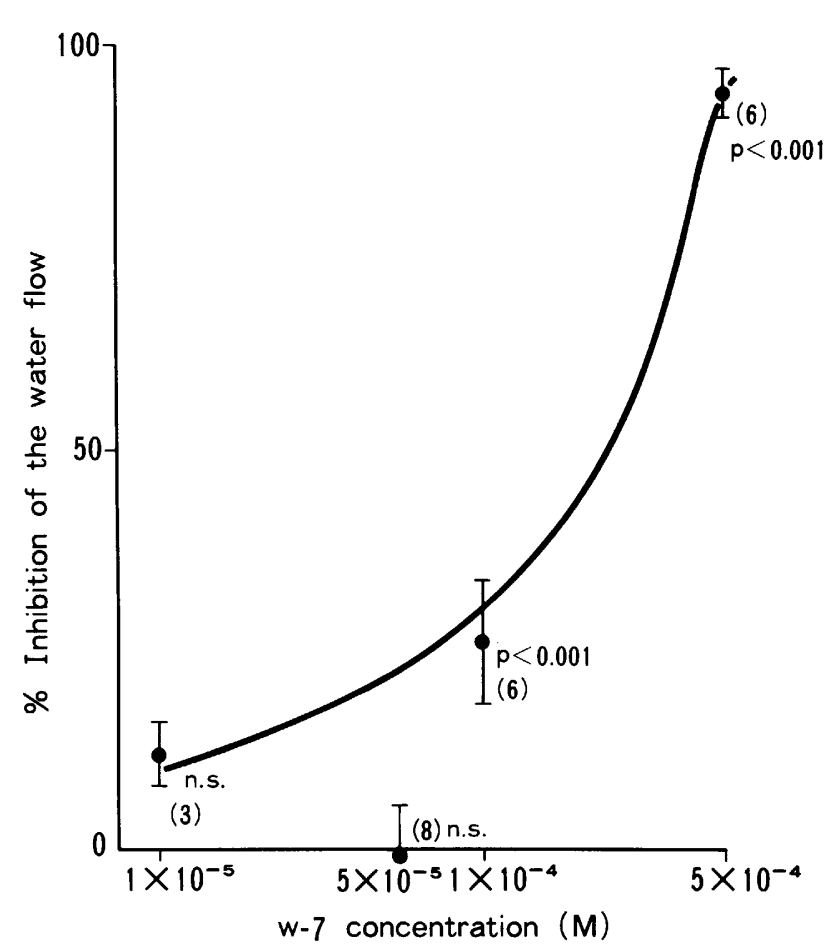

Fig. 3. Effects of W-7 on cyclic AMP-stimulated water flow. W-7 was added to the serosal chamber $1 \mathrm{~h}$ before the addition of $5 \mathrm{~mm}$ cyclic AMP.

PGs converted from $\mathrm{PGH}_{2}$, only $\mathrm{PGE}_{2}$ inhibited the water flow at $10^{-8} \mathrm{M}$, but $\mathrm{PGD}_{2}, \mathrm{PGF}_{2 \alpha}$, and $\mathrm{PGI}_{2}$ were incapable of this even at $10^{-7} \mathrm{M}$. Concerning endogenous prostaglandins in the toad bladder, the synthesis of both $\mathrm{PGE}_{2}$ and PGF $_{2 \alpha}$ was stimulated by vasopressin (ZuSMAN et al., 1977; BURCH et al., 1979). That $\mathrm{PGH}_{2}$ has an effect at $10^{-7} \mathrm{M}$ indicates $\mathrm{PGE}_{2}$ physiologically inhibits vasopressin action while $\mathrm{PGF}_{2 \alpha}$ has merely a pharmacological effect.

SCHLONDORFF et al. (1981) found $\mathrm{PGE}_{2}$, with or without vasopressin, to have an effect on water flow, cyclic AMP generation and cyclic AMP-dependent protein kinase activity in the toad bladder. They reported that $10^{-5} \mathrm{MPE}_{2}$ increased cyclic AMP content and kinase ratio even more than vasopressin but had no effect on the rate of water flow, and that $5 \mathrm{mU} / \mathrm{ml}$ vasopressin and $10^{-5} \mathrm{M} \mathrm{PGE}_{2}$ when added together, increased the water flow but had no effect on cyclic AMP content or the kinase ratio compared to that of $\mathrm{PGE}_{2}$ when administered alone. ZUSMAN et al. (1977) were the first to report that vasopressin stimulates $\mathrm{PGE}_{2}$ biosynthesis in the toad bladder, and that $1 \mathrm{mU} / \mathrm{ml}$ vasopressin increases $\mathrm{PGE}_{2}$ synthesis from $0.5 \pm 0.1 \mathrm{pmoles} / \mathrm{min} \cdot \mathrm{hemibladder}$ to $5.0 \pm 0.4$. In a recent study, it was found that when $\mathrm{PGE}_{2}$ biosynthesis in the toad bladder was at a basal level of $0.22 \pm 0.01 \mathrm{pmoles} / \mathrm{min} \cdot \mathrm{hemibladder}$, it was stimulated 5 times as much as by 


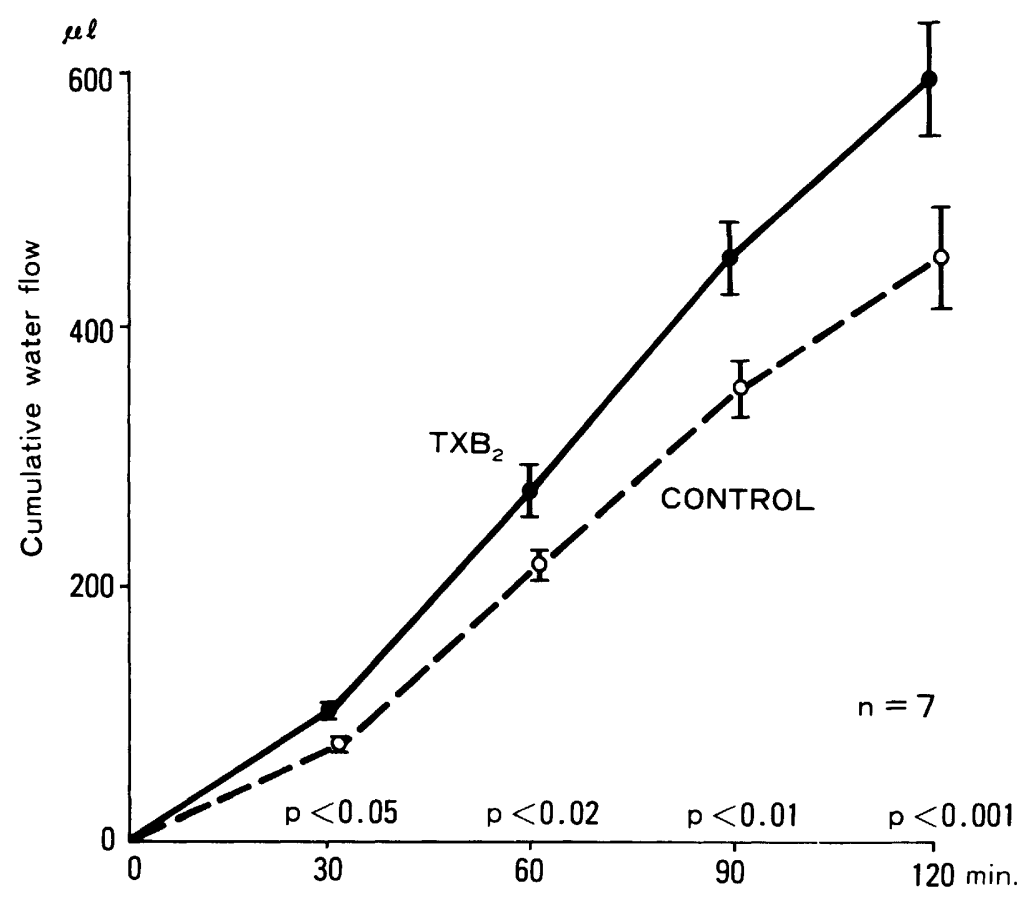

Fig. 4. Effects of $\mathrm{TXB}_{2}$ on vasopressin-stimulated water flow. $\mathrm{TXB}_{2}$, at $1 \times 10^{-7} \mathrm{M}$, was added to the experimental group with $10 \mathrm{mU} / \mathrm{ml}$ vasopressin, and vasopressin alone to the control.

vasopressin (BuRCH et al., 1980) and when at a basal level of $0.27 \pm 0.05$ pmoles/ $\mathrm{min} \cdot \mathrm{mg}$ prot., it was stimulated by $5 \mathrm{mU} / \mathrm{ml}$ vasopressin to $0.53 \pm 0.09$ (BURCH and HALUSHKA, 1982). After removing the bladder from the toads, a preparatory period of no more than $2 \mathrm{~h}$ is necessary prior to the start of the experiment. During this period, the accumulation of $\mathrm{PGE}_{2}$ in a hemibladder may be as much as $10^{-11} \mathrm{M}$ without assuming any degradation. Compared to the endogenous generation of $\mathrm{PGE}_{2}, 10^{-5} \mathrm{M}$ of $\mathrm{PGE}_{2}$ used by SCHOLONDORFF et al. (1981) to demonstrate the dissociation of cyclic AMP levels and kinase ratio from the hydro-osmotic response in the toad bladder, is extremely high, and may not be a physiological concentration. They found that low doses of $\mathrm{PGE}_{2}$, such as $10^{-7}$ and $10^{-8} \mathrm{M}$, have no effect on $5 \mathrm{~mm}$ cyclic AMP-stimulated water flow, but could find no dose-dependent inhibitory effect at concentrations from $10^{-9}$ to $10^{-6} \mathrm{M}$. In the present study, $\mathrm{PGE}_{2}$ significantly inhibited the cyclic AMP-stimulated water flow at $10^{-9}$ to $10^{-6} \mathrm{M}$, but no dose-dependency could be observed, showing agreement of our results with those of SCHLONDORFF et al. (1981) in regard to the effects of low doses of $\mathrm{PGE}_{2}$ on cyclic AMP action.

Figure 1 shows different half maximum activation doses of indomethacin on vasopressin- and cyclic AMP-stimulated water flow and indicates endogenous 


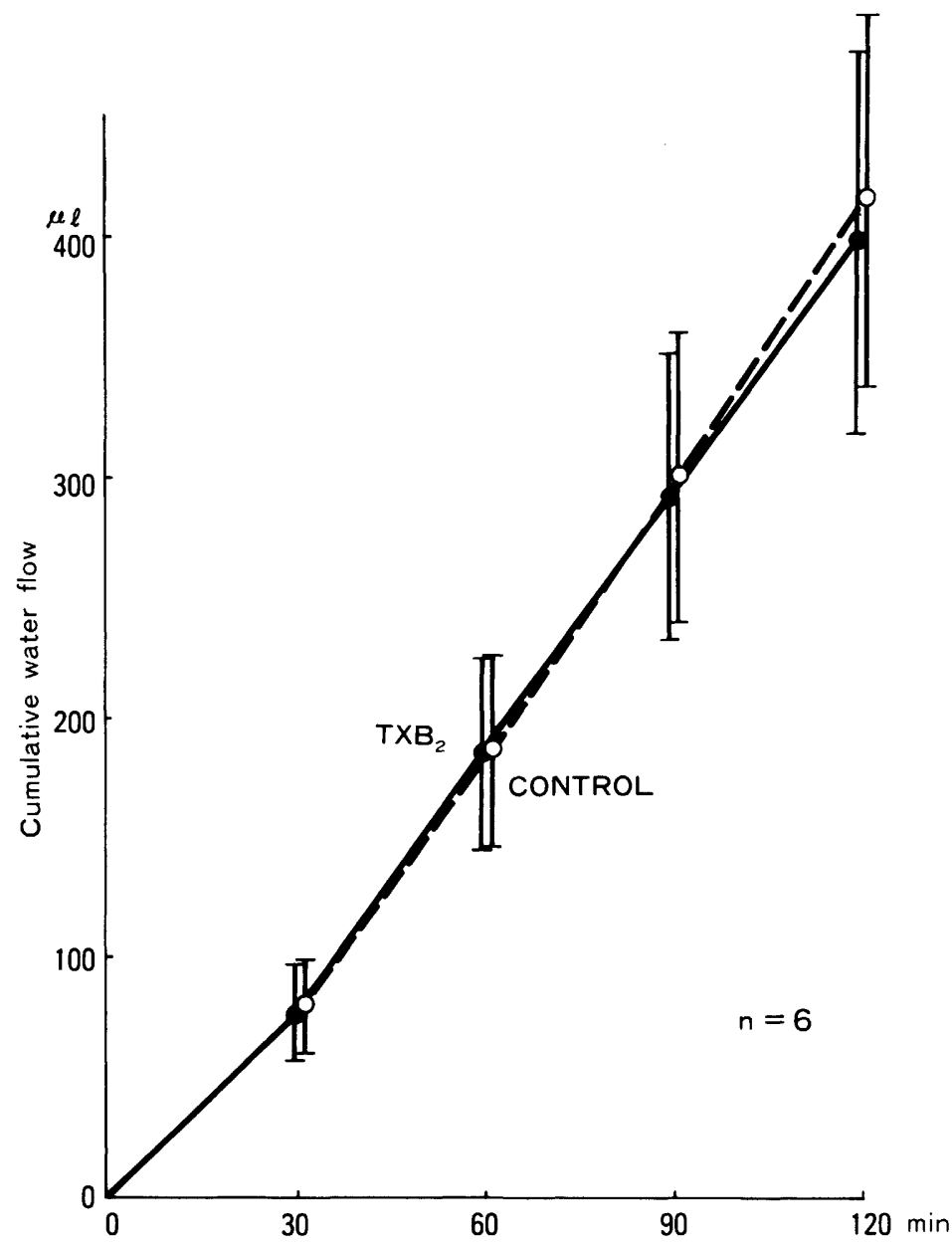

Fig. 5. Effects of $\mathrm{TXB}_{2}$ on cyclic AMP-stimulated water flow. The solid line indicates the experimental group, and the dotted line the control. $\mathrm{TXB}_{2}$, at $1 \times 10^{-6} \mathrm{M}$, was added to the experimental group with $5 \mathrm{~mm}$ cyclic AMP, and cyclic AMP alone to the control.

$\mathrm{PGE}_{2}$ to have a different mode of action on steps at the site of and following cyclic AMP generation. Our data show that $\mathrm{PGE}_{2}$ inhibits both steps at the site of cyclic AMP generation and a step(s) distal to cyclic AMP, and that the action at the site of cyclic AMP generation has physiological significance while that at a step(s) distal to cyclic AMP may not be physiological. Recently, BURCH and HalushKa (1984) reported that vasopressin reduced the intra-cellular $\mathrm{Ca}^{2+}$ concentration while $\mathrm{PGE}_{2}$ increased it. It has been well known that $\mathrm{Ca}^{2+}$ inhibits adenylate cyclase activity (MARUMO and EDELMAN, 1971; BIRNBAUMER, 1973) at relatively high concentration. Taken together, it is suggested that $\mathrm{PGE}_{2}$ may inhibit vasopressin-stimulated 
adenylate cyclase activity by increasing intracellular $\mathrm{Ca}^{2+}$ concentration.

The syntheses of thromboxanes are known to be stimulated by vasopressin (BurCH et al., 1979; BisORdi et al., 1980; BuRCH and HAluSHKA, 1982). However, the authors of those reports do not provide a clear indication as to whether the effects of $\mathrm{TXB}_{2}$ are exerted at the site of or distal to cyclic AMP generation. BuRCH and HALushK (1980) observed that $\mathrm{TXB}_{2}$ alone stimulated the water flow in the toad bladder, though we were unable to do so. We found $\mathrm{TXB}_{2}$ to enhance vasopressin-stimulated water flow but to have no effect on cyclic AMP-stimulated. At low concentrations, imidazole (BURCH et al., 1980a,b) and OKY-1581 (MARUMO, 1985), both thromboxane synthesis inhibitors, reduced vasopressinstimulated water flow, strongly indicating the possibility that $\mathrm{TXB}_{2}$ stimulates vasopressin action at the site of cyclic AMP generation in the toad bladder. Thus, $\mathrm{PGE}_{2}$ and $\mathrm{TXB}_{2}$ were concluded to be negative or positive modulators of vasopressin-stimulated water flow at the step(s) of the site of cyclic AMP generation, under the physiological condition.

This work was supported in part by a research grant for Cardiovascular Diseases (C589) from the Ministry of Health and Welfare in Japan. This work was presented in part at the 29th Congress of International Union of Physiological Sciences, September 1983, Sydney.

\section{REFERENCES}

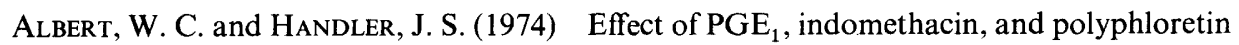
phosphate on toad bladder response to ADH. Am. J. Physiol., 226: 1382-1386.

Beck, N. P., Kaneko, T., Zor, U., Field, J. B., and Davis, B. B. (1971) Effects of vasopressin and prostaglandin $\mathrm{E}_{1}$ on the adenyl cyclase-cyclic $3^{\prime}, 5^{\prime}$-adenosine monophosphate system of the renal medulla of the rat. J. Clin. Invest., 50: 2461-2465.

BiRnBAUMER, L. (1973) Hormone-sensitive adenyl cyclases: Useful models for studying hormone receptor functions in cell-free system. Biochim. Biophys. Acta, 300: 129-158.

Bisordi, J. E., SCHLONDORFF, D., and HAYS, R. M. (1980) Interaction of vasopressin and prostaglandins in the toad urinary bladder. J. Clin. Invest., 66: 1200-1210.

Burch, R. M. and HalushKa, P. V. (1980) Thromboxane and stable prostaglandin endoperoxide analogs stimulate water permeability in the toad urinary bladder. $J$. Clin. Invest., 66: 1251-1257.

BurCH, R. M. and HalushKa, P. V. (1982) Vasopressin stimulates prostaglandin and thromboxane synthesis in toad bladder epithelial cells. Am. J. Physiol., 243: F593F597.

Burch, R. M. and HalushKa, P. V. (1984) ADH or theophylline-induced changes in intracellular free and membrane-bound calcium. Am. J. Physiol., 247: F939-F945.

BurCh, R. M., KNAPP, D. R., and HalushKa, P. V. (1979) Vasopressin stimulates thromboxane synthesis in the toad urinary bladder: Effects of Imidazole. J. Pharmacol. Exp. Ther., 210: $344-348$.

BurCh, R. M., KNaPP, D. R., and HalushKa, P. V. (1980a) Vasopressin stimulates thromboxane synthesis in the toad bladder: Effects of thromboxane synthesis inhibition. Adv. Prostaglandin Thromboxane Leukotriene Res., 6: 505-509.

BuRCH, R. M., KNAPP, D. R., and HaLuShKA, P. V. (1980b) Vasopressin-stimulated water 
flow is decreased by thromboxane synthesis inhibition or antagonism. Am.J. Physiol., 239: F160-F166.

Flores, A. A. and Sharp, G. W. G. (1972) Endogenous prostaglandins and osmotic water flow in the toad bladder. Am. J. Physiol., 223: 1392-1397.

Hidaka, H., Asano, M., Iwadare, S., Matsumoto, I., Totsuka, T., and Aoki, N. (1978) A novel vascular relaxing agent, $\mathrm{N}$-(6-aminohexyl)-5-chloro-1-naphthalensulfonamide which affects vascular smooth muscular actomyosin. J. Pharmacol. Exp. Ther., 207: $8-15$.

Levine, S. D., KaChadorian, W. A., Levin, D. N., and Schlondorff, D. (1981) Effects of trifluoperazine on function and structure of toad urinary bladder: Role of calmodulin in vasopressin-stimulation of water permeability. J. Clin. Invest., 67: 662-672.

Marumo, F. (1982) Inhibitory effects of 1-idio-3-aminomethyl-5,6,7,8-tetrahydro-2naphthol (ONO-3122) and prostaglandin $\mathrm{H}_{2}$ on vasopressin-induced osmotic water flow in toad bladder. Experientia, 38: 828-829.

Marumo, F. (1985) Effects of ONO-3122 (an enhancer of $\mathrm{PGH}_{2}$ production) and OKY1581 (an inhibitor of $\mathrm{TXA}_{2}$ production) on the vasopressin-induced water flow in the toad bladder. Pharmacology, 31: 34-39.

Marumo, F. and Edelman, I. S. (1971) Effects of $\mathrm{Ca}^{++}$and prostaglandin $\mathrm{E}_{1}$ on vasopressin activation of renal adenyl cyclase. J. Clin. Invest., 50: 1613-1620.

Marumo, F. and KiKawada, R. (1974) Effects of phospholipase C on the permeability of the toad bladder. Jpn. Circ. J., 38: 271-276.

Omachi, R. S., Robbie, D. E., Handler, J. S., and OrLofF, J. (1974) Effects of ADH and other agents on cyclic AMP accumulation in the toad bladder epithelium. Am. J. Physiol., 226: 1152-1157.

Orloff, J., Handler, J. S., and Bergstrom, S. (1965) Effect of prostaglandin (PGE 1 ) on the permeability response of toad bladder to vasopressin, theophylline and adenosine 3',5'-monophosphate. Nature, 205: 397-398.

Schlondorff, D., Carvounis, C. P., Jacoby, M., Satriano, J. A., and Levine, S. D. (1981) Multiple sites for interaction of prostaglandin and vasopressin in toad urinary bladder. Am. J. Physiol., 241: F625-F631.

Zusman, R. M., Keiser, H. R., and HandleR, J. S. (1977) Vasopressin-stimulated prostaglandin $\mathrm{E}$ biosynthesis in the toad bladder: Effect on water flow. J. Clin. Invest., 60: 1339-1347. 